Review

\title{
Small Molecules of Marine Origin as Potential Anti-Glioma Agents
}

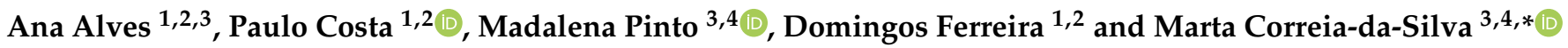 \\ 1 UCIBIO, REQUIMTE, Faculty of Pharmacy, University of Porto, Rua de Jorge Viterbo Ferreira 228, \\ 4050-313 Porto, Portugal; anadaniela92@hotmail.com (A.A.); pccosta@ff.up.pt (P.C.); domingos@ff.up.pt (D.F.) \\ 2 Laboratory of Pharmaceutical Technology, Department of Chemical Sciences, Faculty of Pharmacy, \\ University of Porto, Rua de Jorge Viterbo Ferreira 228, 4050-313 Porto, Portugal \\ 3 Laboratory of Organic and Pharmaceutical Chemistry, Department of Chemical Sciences, Faculty of Pharmacy, \\ University of Porto, Rua de Jorge Viterbo Ferreira 228, 4050-313 Porto, Portugal; madalena@ff.up.pt \\ 4 Interdisciplinary Center of Marine and Environmental Research (CIIMAR), University of Porto, Terminal de \\ Cruzeiros do Porto de Leixões Avenida General Norton de Matos P, 4450-208 Matosinhos, Portugal \\ * Correspondence: m_correiadasilva@ff.up.pt; Tel.: +351-22-042-8689
}

Citation: Alves, A.; Costa, P.; Pinto, M.; Ferreira, D.; Correia-da-Silva, M. Small Molecules of Marine Origin as Potential Anti-Glioma Agents.

Molecules 2021, 26, 2707. https:// doi.org/10.3390/molecules26092707

Academic Editor: Changsheng Zhang

Received: 16 April 2021

Accepted: 3 May 2021

Published: 5 May 2021

Publisher's Note: MDPI stays neutral with regard to jurisdictional claims in published maps and institutional affiliations.

Copyright: (c) 2021 by the authors. Licensee MDPI, Basel, Switzerland. This article is an open access article distributed under the terms and conditions of the Creative Commons Attribution (CC BY) license (https:// creativecommons.org/licenses/by/ $4.0 /)$.

\begin{abstract}
Marine organisms are able to produce a plethora of small molecules with novel chemical structures and potent biological properties, being a fertile source for discovery of pharmacologically active compounds, already with several marine-derived agents approved as drugs. Glioma is classified by the WHO as the most common and aggressive form of tumor on CNS. Currently, Temozolomide is the only chemotherapeutic option approved by the FDA even though having some limitations. This review presents, for the first time, a comprehensive overview of marine compounds described as anti-glioma agents in the last decade. Nearly fifty compounds were compiled in this document and organized accordingly to their marine sources. Highlights on the mechanism of action and ADME properties were included. Some of these marine compounds could be promising leads for the discovery of new therapeutic alternatives for glioma treatment.
\end{abstract}

Keywords: glioma; marine compound; drug discovery

\section{Introduction}

The second leading cause of death in the world is cancer, with a total number of 9.6 million (17\% of all deaths) [1]. Glioma is classified by the World Health Organization (WHO) as the most common and aggressive form of central nervous system (CNS) brain tumor and the median overall survival for glioma patients remains around 2 years [2]. WHO classifies gliomas into grades I to IV based on the level of malignancy determined by histopathological criteria, including astrocytic tumors, astrocytoma, anaplastic astrocytoma and glioblastoma (GBM); oligodendrogliomas; ependymomas and mixed gliomas. Gliomas range from grade I, with the least proliferating lesions that can be cured, to grade IV, called cytotoxic malignant neoplasms, which proliferate quickly and invade surrounding healthy tissues [3]. Current treatment is still inadequate due to some tumor related characteristics (such as glioma cells complex composition and diffuse invasiveness) and to blood brain barrier (BBB) selectivity that inhibits drugs from permeating into the brain tumor mass $[4,5]$. Conventional surgical methods or radiotherapy alone cannot eliminate this kind of tumor, and the relapse is, generally, inevitable [6-8]. The conventional used combinatorial therapy is composed firstly by surgery, and then by radiotherapy and chemotherapy [6,8]. However, surgery is the main component of the standard treatment, because reduces the tumor area. Surgical treatment may be followed by radiotherapy and despite a large number of clinical trials already performed, only modest therapeutic results have been achieved [6]. 


\section{Treatment of Glioma}

Glioma treatment is a challenging task in clinical oncology [9]. Chemotherapy is difficult due to BBB and heterogeneity of this brain cancer [10]. BBB is the main obstacle in routine chemotherapy as it can successfully block many drugs into the bloodstream and hence retard the drug accumulation in the tumor. Additionally, clinical applications are limited by several adverse effects, such as bone marrow suppression, genotoxic, teratogenic and fetotoxic effects. Temozolomide (TMZ, Figure 1A) is the standard care in chemotherapy for glioma, reaching "blockbuster" status in 2010, being the option already approved by Food and Drug Administration (FDA) [11].<smiles>Cn1nnc2c(C(N)=O)ncn2c1=O</smiles><smiles>Cn1c(C(N)=O)cnc1/N=N/N</smiles>

Figure 1. (A)—Temozolomide (TMZ); (B)—3-methyl-(triazen-1-yl)imidazole-4-carboxamide (MTIC).

TMZ is an imidazotetrazine derivative with an amide group and behaves as a prodrug [12], which spontaneously hydrolyzes at physiological pH to 3-methyl-(triazen-1yl)imidazole-4-carboxamide (MTIC, Figure 1B). The main mechanism responsible for TMZ cytotoxicity concerns DNA methylation at positions N7 and O6 in guanine, which leads to the failure of the DNA-free repair system to find a complementary base for methylated guanine, resulting in prolonged DNA cuts and consequently blocks of the cell cycle at the G2-M, triggering apoptosis [13]. Some tumor cells express methyl guanine methyl transferase (MGMT) gene and high levels of MGMT activity in tumor cells have been reported to be associated with a poor response to TMZ. MGMT is a critical DNA repair protein that protects tumor cells from alkylating chemotherapeutic agents [14].

Several molecular modifications have been applied to the TMZ scaffold in order to enhance selectivity, targeting activities and improve efficacy via an increased level of BBB penetrance $[15,16]$. Substitution of the amide group of TMZ for a methylketone increased brain permeability with $69 \%$ of the drug entering the CNS compared with $8 \%$ for TMZ and produced a more effective compound when tested in mice [5]. In this study, the anticancer activity of two new TMZ analogs replaced at C8 with imidazolyl and methyl imidazole, was evaluated. These results indicate that C8 imidazolyl or methylimidazole confer properties such as greater stability or more efficient delivery [17].

With glioma remaining practically incurable and with an associated short average survival, the search for novel drugs to treat this disease with unique structures and diverse mechanisms of action is a current priority.

Several small synthetic molecules have emerged as potential agents for the treatment of GBM. Nearly a hundred small synthetic molecules with inhibitory activity against GBM cell lines have been described in the last 10 years [18]. Most studies have been carried out in vitro on several glioma cell lines, containing U86MG, U87MG, U118MG, U251MG, U373MG, T98G, SF295 and C6. However, some molecules (Figure 2) have already reached advanced stages of preclinical development with proven efficacy in vivo against GBM [19-22]. Considering described targets several protein kinases have been referred such as phosphoinositide 3-kinase (PI3K), dual-specificity tyrosine-regulated kinases (DYRK), pyruvate dehydrogenase kinase 1 (PDK1), casein kinase II (CK2), c-Src, protein kinase $\mathrm{B}(\mathrm{Akt})$, focal adhesion kinase (FAK) and epidermal growth factor receptor (EGFR) [23-26]. In addition, many cellular pathways, enzymes and processes have also been investigated, such as G-quadruplexes, histone deacetylases (HDACs), heat shock protein 90 (HSP90), microtubules, via NF-kB, p53, among others [23-28]. 


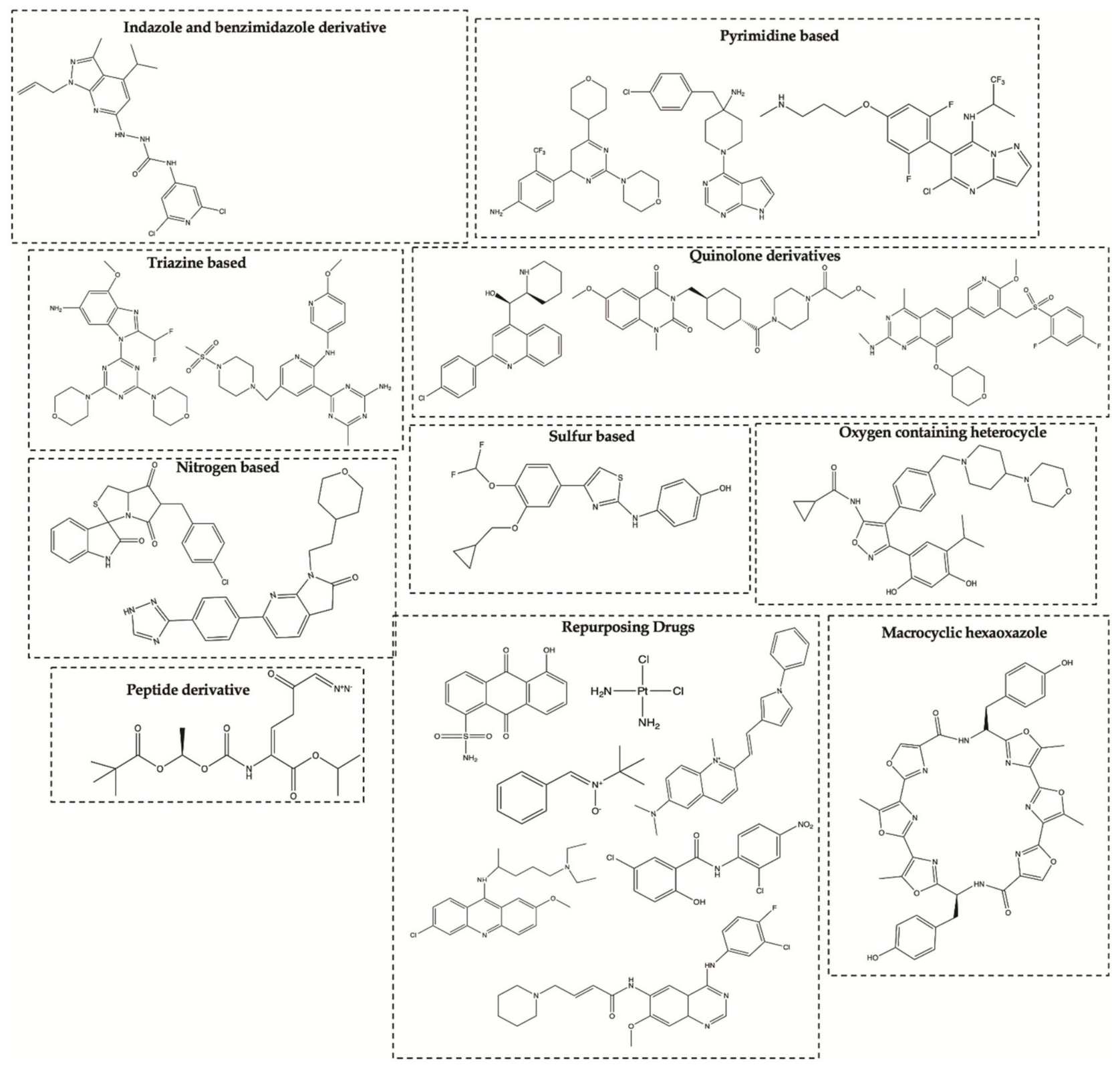

Figure 2. Synthetic compounds that have shown in vivo efficacy against GBM.

\section{Marine Organisms as Sources of Anti-Glioma Compounds}

Interest in the oceans has grown in recent decades due to the enlargement of discovery in quantity and diversity of marine products with interesting biological/pharmacological activities [29-31]. Over the past fifty years, progressive improvements have been made in the exploration of new marine habitats, leading to the isolation of thousands of unique marine natural products [30] for industrial development, such as pharmaceuticals, food ingredients, cosmetics, drug delivery systems (DDS) and industrial enzymes [31-33]. Species such as algae, sponges and corals are in constant competition because they are at high risk of predation, so these species have developed chemical defense mechanisms based on the synthesis of toxic secondary metabolites [34].

In the last decade, FDA has approved a macrolide $\left(\right.$ Halaven $\left.^{\circledR}, 2010\right)$ derived from a sponge (Halichondria okadai) for metastatic breast cancer; an antibody-drug conjugate (Adcetris ${ }^{\circledR}, 2011$ ) isolated from a sea hare (Dolabella auricularia) for use in Hodgkin's lymphoma and anaplastic large cell lymphoma, and an alkaloid (isolated from a tunicate) 
(Yondelis $\left.{ }^{\circledR}, 2015\right)$ for ovarian cancer and soft tissue sarcoma $[35,36]$. Therefore, the search for antitumor compounds derived from the sea has proved to be worthy.

The purpose of this review is to bring together marine compounds described with anti-glioma effects in the last decade. Most of the anti-glioma compounds discovered were isolated from anemones, seaweed (brown and green), bacteria, sponges, invertebrates, fungi and corals and will be following described accordingly to these sources.

\subsection{Marine Anemone}

An extract prepared from the culture of a sea anemone-derived actinomycete Streptomyces sp. ZZ406 [33] was found to have activity in inhibiting the proliferation of glioma cells and reducing the production of lactate in glioma cells [37-39]. Chemical investigation of this crude active extract led to the isolation and identification of compounds 1-4 (Figure 3) [40]. The structure of compound 1 was elucidated as 1-hydroxymethyl-8hydroxy-anthraquinone-3-carboxylic acid, a new anthraquinone [40]. These new compounds 1-4 were also tested for their activity in inhibiting the proliferation of human glioma U87MG, U251 and SHG44 cells by sulforhodamine B (SRB) assay. Doxorubicin (DOX), a chemotherapeutic drug, was used as a positive control. It has been found that $\mathbf{1}$ had potent activity against different glioma cells with $\mathrm{IC}_{50}$ values in a range of 4.7 to $8.1 \mu \mathrm{M}$, and good stability. Compound 2, a chromone, showed $\mathrm{IC}_{50}$ values of 21.6-25.8 $\mu \mathrm{M}$. Unfortunately, the new peptide 3 and new pyrazolidine derivative 4 were inactive. DOX had an antiproliferative activity with $\mathrm{IC}_{50}$ values of 1.9-9.6 $\mu \mathrm{M}$. Pyrazolidenes 5 and 6 were also assayed for their activity against glioma. The results showed that both pyrazolidines 5 and 6 also had anti-glioma activity with $\mathrm{IC}_{50}$ values of 0.5 to $3.0 \mu \mathrm{M}$ for 5 and 10.4 to $36.3 \mu \mathrm{M}$ for $\mathbf{6}$. The cytotoxicity $\left(\mathrm{CC}_{50}\right)$ of the two active compounds $\mathbf{1}$ and $\mathbf{2}$ towards normal human astrocytes (HA) was also evaluated and an $\mathrm{IC}_{50}$ higher than $100 \mu \mathrm{M}$ was found showing high selectivity index (>12.3 to 21.3). They were also analyzed for their effects on the expression levels of important tumor glycolytic (regulatory) enzymes-hexokinase (HK2), 6-phosphofructo-2-kinase/2,6-bisphosphatase 3 (PFKFB3), pyruvate kinase M2 (PKM2) and lactate dehydrogenase (LDH5), highly expressed in U87MG 27 cells. Compounds 1 and 2 clearly reduced the levels of HK2, PFKFB3, PKM2 and LDH5 expression [40].<smiles>O=C1c2cccc(O)c2C(=O)c2c(CO)cc(O)cc21</smiles><smiles>CC(=O)N1CC(C(=O)O)CN1C(=O)C(C)C</smiles><smiles>Cc1cc(=O)c2c(CC(=O)C[C@H](O)CC(=O)O)cccc2o1</smiles><smiles>COC(=O)[C@@H]1CN(C(C)=O)N(C(C)=O)[C@H]1C(C)C</smiles><smiles>CC(=O)N[C@H]1CC(C)CN(C(CO)C(=O)N[C@@H](C)C(=O)O)C1=O</smiles>
3<smiles>C=C1CN(C(C)=O)N(C(C)=O)C1</smiles>

Figure 3. Compounds 1-6 isolated from the culture of Streptomyces sp. ZZ406 [40].

\subsection{Seaweed}

Seaweeds (also known as macroalgae) comprise a very large number of species of marine algae that are macroscopic and multicellular. This designation "seaweeds" includes Rhodophyta (red), Phaeophyta (brown) and Chlorophyta (green) macroalgae. Only one compound isolated from red algae was described as active in glioma cells and its mechanism of action is thought to be related to the inactivation of the AKt pathway. Regarding brown algae, at least three compounds from different chemical classes, phorotannin, sac- 
charide and carotenoids, were described. It should also be noted that these compounds have different mechanisms of action: (i) eckol was shown to suppress PI3K-AKt activity and inhibit the Ras-Raf-1 pathway, (ii) fucoidan was reported to stimulate differentiation of osteoblasts via c-Jun N-terminal kinase (JNK), (iii) fucoxanthin showed preventive effects through different mechanisms of action. A large number of studies [41-44] have shown that these different mechanisms of anticancer action include anti-proliferation, suppression of angiogenesis, cell cycle arrest, apoptosis induction and antidrug potential. Regarding green algae, four compounds from the same chemical class, Bafilomycins, were described with antiproliferative activity on human glioma cells [43].

\subsubsection{Red Seaweeds}

Aplysin (7, Figure 4), is a bromo sesquiterpene isolated from Laurencia tristicha. This compound was found to reduce the number of invasive glioma cells U87MG and U251MG, as well as primary glioma cells, in a dose-dependent manner [44]. Furthermore, the Akt pathway was inactivated by aplysin, and reactivation of the Akt pathway rescued its inhibitory effect on proteins associated with invasion and the invasiveness of U87MG cells. The Akt pathway is related to cell proliferation, protein synthesis, survival and motility and increased expression of these proteins has been associated with tumors with a worse prognosis. No cytotoxicity for normal cells (normal neuronal cell line, HCN2, normal liver cell line, L-02, normal endothelial cell line, HUV-EC-C and normal lung fibroblast cell line, MRC-5) was observed in the presence of aplysin $(400 \mu \mathrm{g} / \mathrm{mL})$ [44].<smiles>Cc1ccc2c(c1Br)[C@]1(C)CC[C@@H](C)[C@]1(C)O2</smiles>

Figure 4. Sesquiterpene 7 isolated from marine red seaweed [44].

\subsubsection{Brown Seaweeds}

Eckol (8, Figure 5), is a phlorotannin component of some brown algae, including Ecklonia cava (Laminariaceae), and was shown to protect cells from $\mathrm{H}_{2} \mathrm{O}_{2}$-induced oxidative stress via radical quenching and catalase activation [41]. In this study, phosphoinositide 3-kinase (PI3K)-Akt and Ras-Raf-1-Erk pathways are previously found to be activated in cancer stem-like cells whether Eckol inhibits these signaling pathways. Treatment with eckol caused a marked suppression of PI3K-Akt activities, and completely inhibited Ras-Raf- 1 interaction and Raf-1 and Erk activations in sphere-forming glioma stem-like cells. It was hypothesized that eckol may enhance the sensitivity of glioma stem-like cells to anticancer treatments such as ionizing radiation or chemical drugs via inhibition of PI3K-Akt and Ras-Raf-1-Erk pathways. 


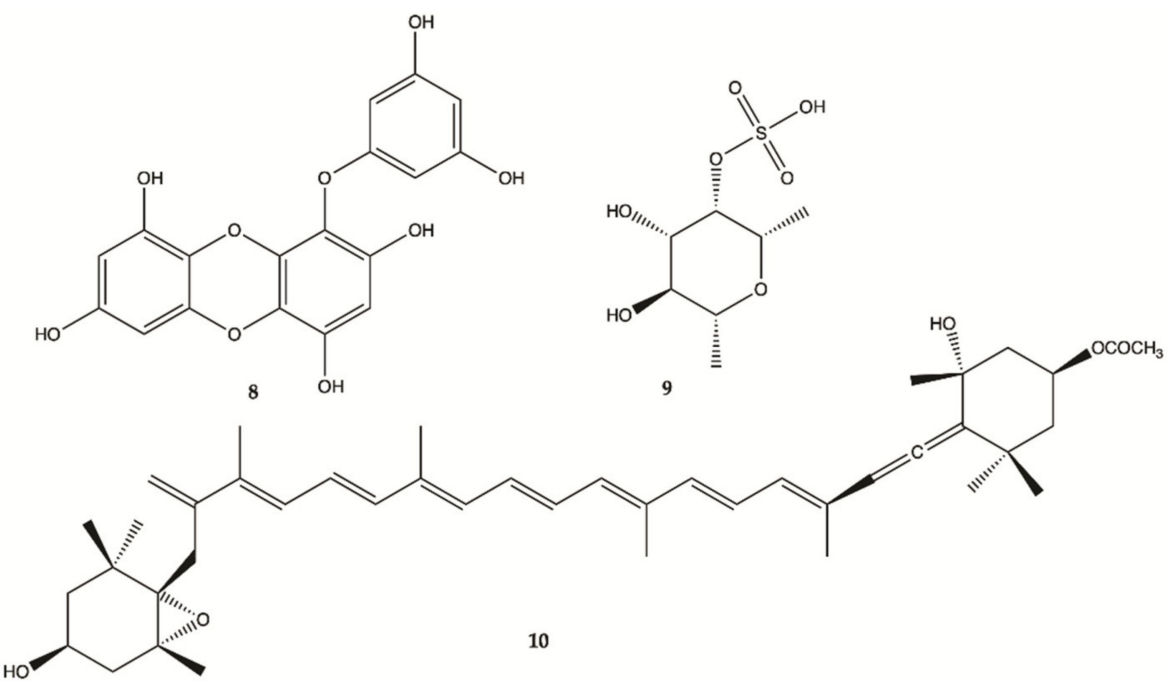

Figure 5. Compounds $\mathbf{8 - 1 0}$ isolated from brown seaweed [41,45].

Fucoidan (9, Figure 5), a sulfated saccharide isolated from Fucus vesiculosus, inhibited both glioma cell-induced and monocyte-induced angiogenesis in vitro. The effects of fucoidan on T98G-induced or THP1-induced angiogenesis were also evaluated by tube formation assay using conditioned medium of fucoidan-treated cells. After $24 \mathrm{~h}, \mathrm{~T} 98 \mathrm{G}$ and THP1 cell-induced tube formation was inhibited by fucoidan (100 mg/mL) [45]. No apoptosis was observed in human lens epithelial cells (SRA) indicating the specific action of fucoxanthin against carcinogenic cells. Fucoxanthin (10, Figure 5) is one of the most abundant carotenoids and contributes to more than $10 \%$ of the estimated total production of carotenoids in nature, especially in the marine environment [46]. Fucoxanthin is a pigment that, along with chlorophylls and $\beta$-carotene, is widely distributed in brown algae and diatoms. Fucoxanthin has been described with different mechanisms of action including anti-proliferation cell cycle arrest, apoptosis induction, suppression of angiogenesis among others [42].

\subsubsection{Green Seaweeds}

A methanol extract obtained from a culture of an actinomycete Streptomyces sp. HZP$2216 \mathrm{E}$ isolated from marine green algae Ulva pertusa significantly inhibit proliferation of human glioma cells. Therefore, 4 Bafilomycins were isolated from this extract (11-14, Figure 6), and assayed for their activity against proliferation of human glioma U87-MG, U251 and SHG44 cells as well as rat glioma C6 cells by SRB assay. Bafilomycin A1 (11), bafilomycin D (12), 9-hydroxybafilomycin D (13) and 23-O-butyrylbafilomycin D (14) showed potent activity in the suppressing of the proliferation of the four tested glioma cell lines with $\mathrm{IC}_{50}$ values in a range from 0.35 to $2.95 \mu \mathrm{M}$. The control DOX had similar activity with $\mathrm{IC}_{50}$ values of 0.48 to $1.76 \mu \mathrm{M}$ [43]. Unfortunately, these compounds also showed potent activity against $\mathrm{HA}$ with $\mathrm{IC}_{50}$ values of $0.22 \mu \mathrm{M}$ for $11,0.42 \mu \mathrm{M}$ for $12,0.06 \mu \mathrm{M}$ for 13, and $0.14 \mu \mathrm{M}$ for 14 . 


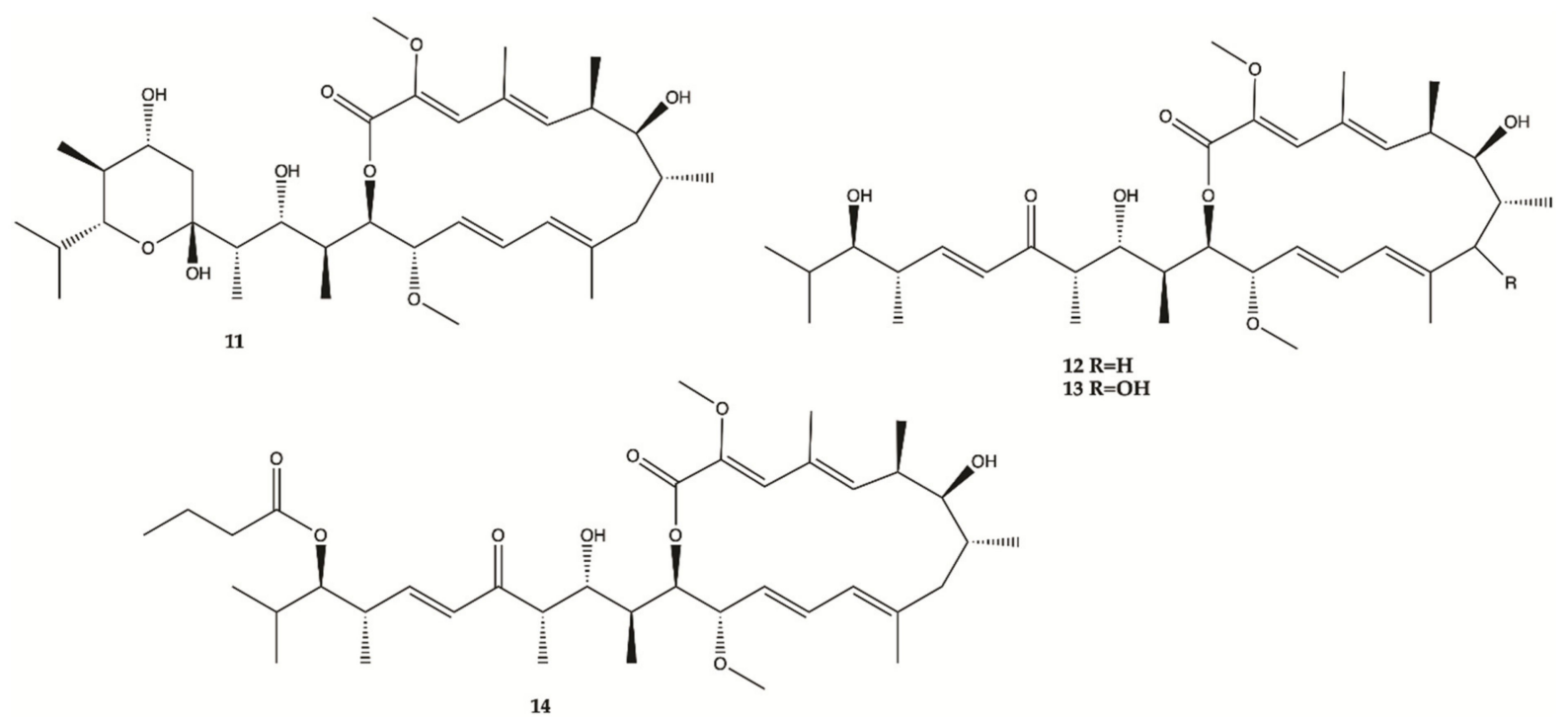

Figure 6. Bafilomycins 11-14 isolated from marine green algae Ulva pertusa [43].

\subsection{Marine Bacteria}

Marine bacteria are organisms from which various compounds from different chemical families have been isolated, such as Actinomycins, Fradimicins and Streptoglutarimides. Regarding Actinomycins, three compounds were isolated, showing significant inhibition of the growth and proliferation of different glioma cell lines. Interestingly, it was discovered that Actinomycins D (15) negatively regulate various metabolic enzymes of the glioma from different metabolic pathways (glycolysis, glutaminolysis and lipogenesis). In this study, Actinomycins D (15) and V (16) showed values of $\mathrm{IC}_{50}$ of $1.01-10.06 \mu \mathrm{M}$ and 0.42 to $1.80 \mu \mathrm{M}$, respectively. From the Fradimicins, two compounds were identified and isolated showing potent activity against glioma cells, but Fradimicin (18) showed an $\mathrm{IC}_{50}$ of $0.47 \mu \mathrm{M}$ and induced apoptosis and necrosis of HCT-15, SW620, C6 cells and blocked HCT-15 cells in the phase G0/G1. Finally, from Streptoglutarimides, only two compounds were also isolated, with compound 21 showing an $\mathrm{IC}_{50}$ value of $0.05-0.22 \mu \mathrm{M}$ and revealing more potent antiproliferative activity against glioma cells than compound 20.

Three Actinomycins D (15), V (16) and X0 $\beta$ (17) (Figure 7) produced by a Streptomyces sp. strain, ZZ338, isolated from sea squirts, were tested for their activity against the proliferation of human glioma U251 and SHG44 cells and rat glioma C6. The data obtained from this study indicated that the referred three Actinomycins had potent activity against the proliferation of the three tested tumor cell lines, with $\mathrm{IC}_{50}$ values from 1.01 to $10.06 \mathrm{nM}$ for actinomycin $\mathrm{D}$ (15), 0.42 to $1.80 \mathrm{nM}$ for actinomycin $\mathrm{V}$ (16), 3.26 to $25.18 \mathrm{nM}$ for actinomycin $\mathrm{X} 0 \beta$ (17), while the control DOX showed activity with $\mathrm{IC}_{50}$ values in a range from 0.70 to $9.61 \mu \mathrm{M}$. In this study, actinomycin D (15) was found to significantly downregulate the expression levels of several glioma metabolic enzymes, including HK2 and PKM2 from glycolysis, GLS from glutaminolysis and FASN from lipogenesis [37].

Two new Fradimicins (18 and 19, Figure 8) were isolated and identified from marine Streptomyces fradiae PTZ0025. Fradimicins 18 and 19 showed significantly inhibit cell growth of rat C6 glioma cells. Fradimycin 19 induced apoptosis and necrosis of C6 cells [47]. 


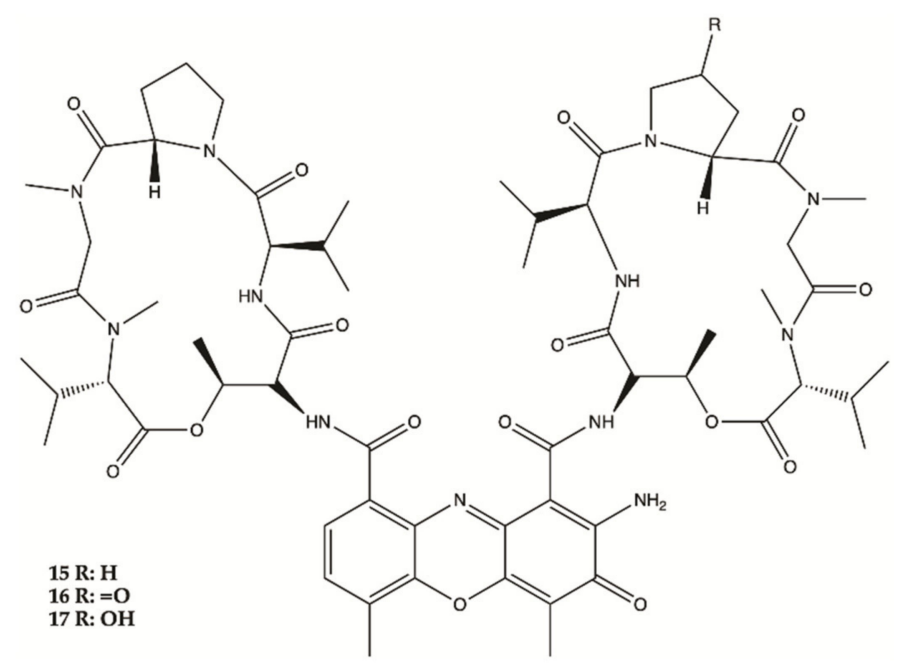

Figure 7. Actinomycins 15-17 isolated from sea squirts [37].

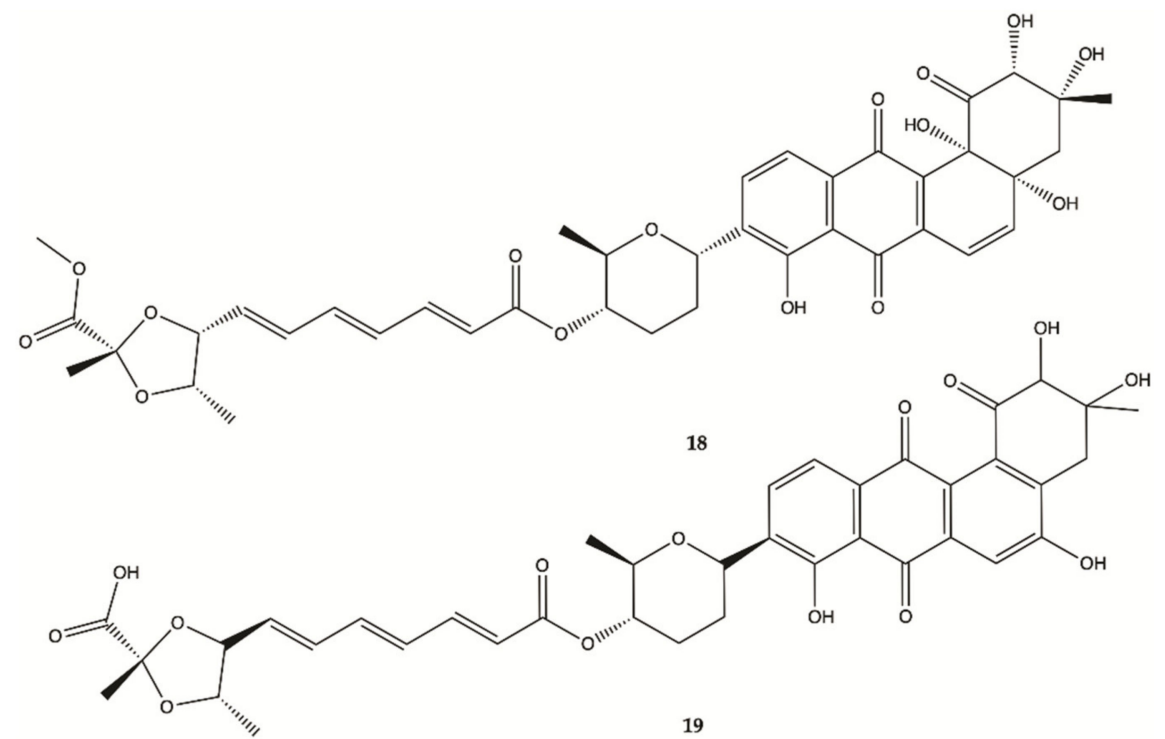

Figure 8. Fradimicins 18 and 19 isolated from Streptomyces fradiae PTZ0025 [47].

Streptoglutarimides $\mathbf{2 0}$ and $\mathbf{2 1}$ (Figure 9) were isolated from an actinomycete, Streptomyces sp. ZZ741. They showed potent antiproliferative activity against human glioma U87MG and U251 cells with $\mathrm{IC}_{50}$ values of $1.5-3.8 \mu \mathrm{M}$ for 19 and $0.05-0.22 \mu \mathrm{M}$ for 20 [48].<smiles>C[C@H]1C[C@H](C)[C@@H](CC2CC(=O)NC(=O)C2)C(=O)[C@H]1C</smiles><smiles>C[C@H]1C[C@H](O)C[C@](C)([C@H](O)CC2CC(=O)NC(=O)C2)C1=O</smiles>

Figure 9. Streptoglutarimides 20 and $\mathbf{2 1}$ isolated from Actinomycete Derivates Streptomyces sp. ZZ741 [48].

\subsection{Marine Invertebrates}

One anthraquinone and three alkaloids were isolated from marine invertebrates and studied in glioma cell lines as follows. 
An anthraquinone (22, Figure 10), isolated from the marine echinoderm Comanthus sp., showed prominent toxic effects to $\mathrm{C} 6$ glioma cells up to $50 \mu \mathrm{M}$ ( $\mathrm{IC}_{50}$ value of $\left.23.2 \mu \mathrm{M}\right)$. A significant increase in caspase $3 / 7$ activity was found in $\mathrm{C} 6$ glioma cells showing apoptotic cell death. Incubation of C6 cells with $25 \mu \mathrm{M}$ of compound 22 resulted in an increase in LDH activity [49].<smiles>CCCc1cc(O)c2c(c1)C(=O)c1cc(O)cc(O)c1C2=O</smiles>

Figure 10. Antraquinone 22 isolated from the marine Echinoderm Comanthus sp [49].

More recently, a series of 1,2,3,4-tetrahydroisoquinoline alkaloids 23-25 were obtained from Carribean Tunicate Ecteinascidia tubinata [50] with potent anti-cancer activities, including ecteinascidin-770 (23, ET-770), renieramycin $\mathrm{M}(\mathbf{2 4}, \mathrm{RM})$, as well as a $2^{\prime}-\mathrm{N}-$ $4^{\prime \prime}$-pyridinecarbonyl derivative of ET-770 (25) (Figure 11). These compounds induced apoptosis of U373MG cells at nanomolar concentrations. The molecular pathways responsible for cytotoxic effects of these compounds on the human glioma cell line U373MG were characterized. The ErbB signaling pathway (EGFR) is composed of FAK/protein tyrosine kinase 2 (PTK2), Akt3, and glycogen synthase kinase 3 beta (GSK3B), serving as key molecules involved in cell movement and nervous system development. Compounds 23-25 showed a significant relationship with the cell cycle pathway, where cell division cycle 25A (CDC25A) acts as a central molecule. Finally, we found that a specific inhibitor of GSK3B induced apoptosis of U373MG cells, supporting an anti-apoptotic role of GSK3B. These observations indicate that molecular network analysis is a useful approach not only to characterize the pathways relevant to the glioma but also to identify effective targets for network-based drugs [50]. These alkaloids induced apoptosis of glioma cells through shared molecular mechanisms involving various pathways and targets, that play a key role in the survival and invasion of glioma cells [50].

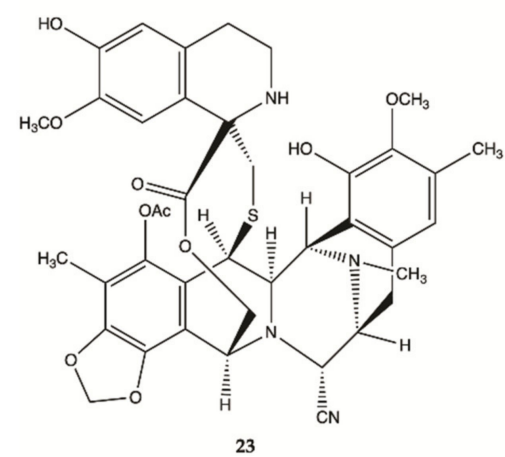

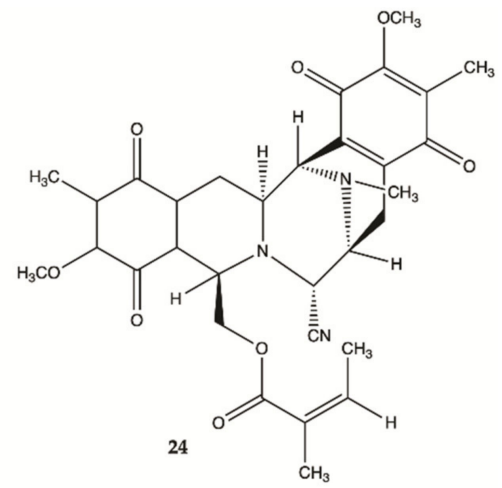

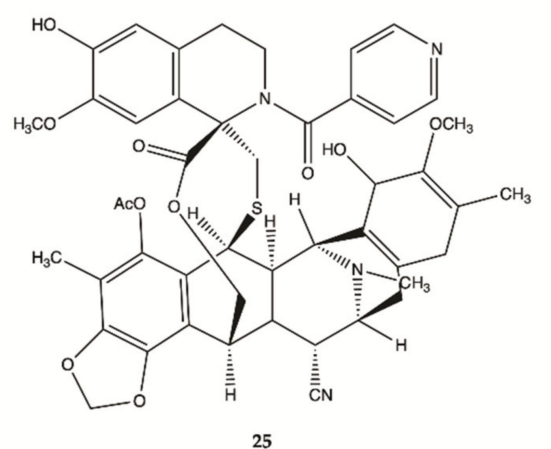

Figure 11. Alkaloids 23-25 isolated from Thai marine invertebrates [50]. 


\subsection{Marine Sponges}

Different chemical classes of compounds with anti-glioma activity, namely alkaloides, plakortide, sesquiterpenes and sphingosinas, were isolated from marine sponges.

Steroidal alkaloids 26-28 (Figure 12) were isolated from a sample of Corticium sp. collected from Porth Havannah, Vanuatu, South Pacific. Cytotoxicity was evaluated in a rat glioma C6 and murine monocyte/macrophages (RAW 264) cell lines. Compound $\mathbf{2 8}$ to be the most active with an $\mathrm{IC}_{50}$ value of $1.4 \mu \mathrm{g} / \mathrm{mL}$ against rat glioma $\mathrm{C} 6$, whereas compound 26 was without effect RAW 264 cell lines, but the compounds $27\left(\mathrm{IC}_{50} 61.0 \mu \mathrm{g} / \mathrm{mL}\right)$ and 28 $\left(\mathrm{IC}_{50} 16.2 \mu \mathrm{g} / \mathrm{mL}\right.$ ) were shown to be cytotoxic against RAW 264 [51].

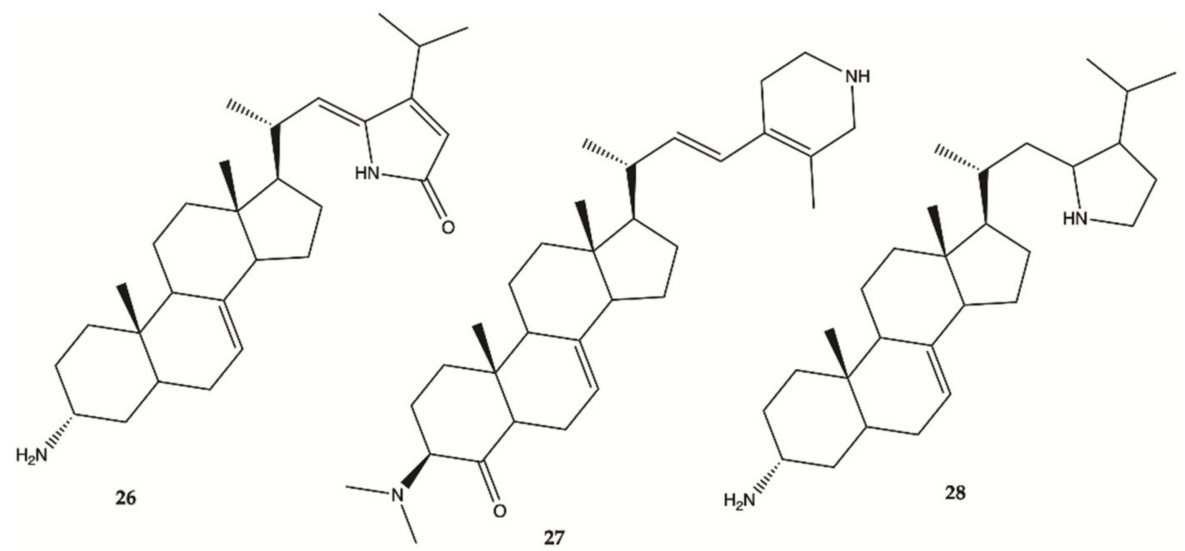

Figure 12. Alkaloids 26-28 isolated from Marine Sponge Corticium sp. [51].

Compound 29 (Figure 13) isolated from sponges from the Caribbean Sea was tested for its anticancer effects on human malignant glioma cells U87MG and U373MG. Compound 29 had an $\mathrm{IC}_{50}$ value of $4.0 \mu \mathrm{mol} / \mathrm{L}$ on U373MG cell line [52].<smiles>CC/C=C/C(CO)C/C=C/[C@]1(CO)C[C@H](CC)[C@@H](CO)OO1</smiles>

29

Figure 13. Plakortide 29 isolated from Marine Sponge Plakortis halichondroides [52].

Sesquiterpene 30-38 (Figure 14) were isolated from the extracts of the Hawaiian marine sponge Dactylospongia elegans. These nine compounds showed strong to moderate cytotoxicity ( $\left(\mathrm{IC}_{50}\right.$ values of $2.4-19.4 \mu \mathrm{M}$ ) against the human glioma cancer cell line, U251MG (Table 1) [53]. 

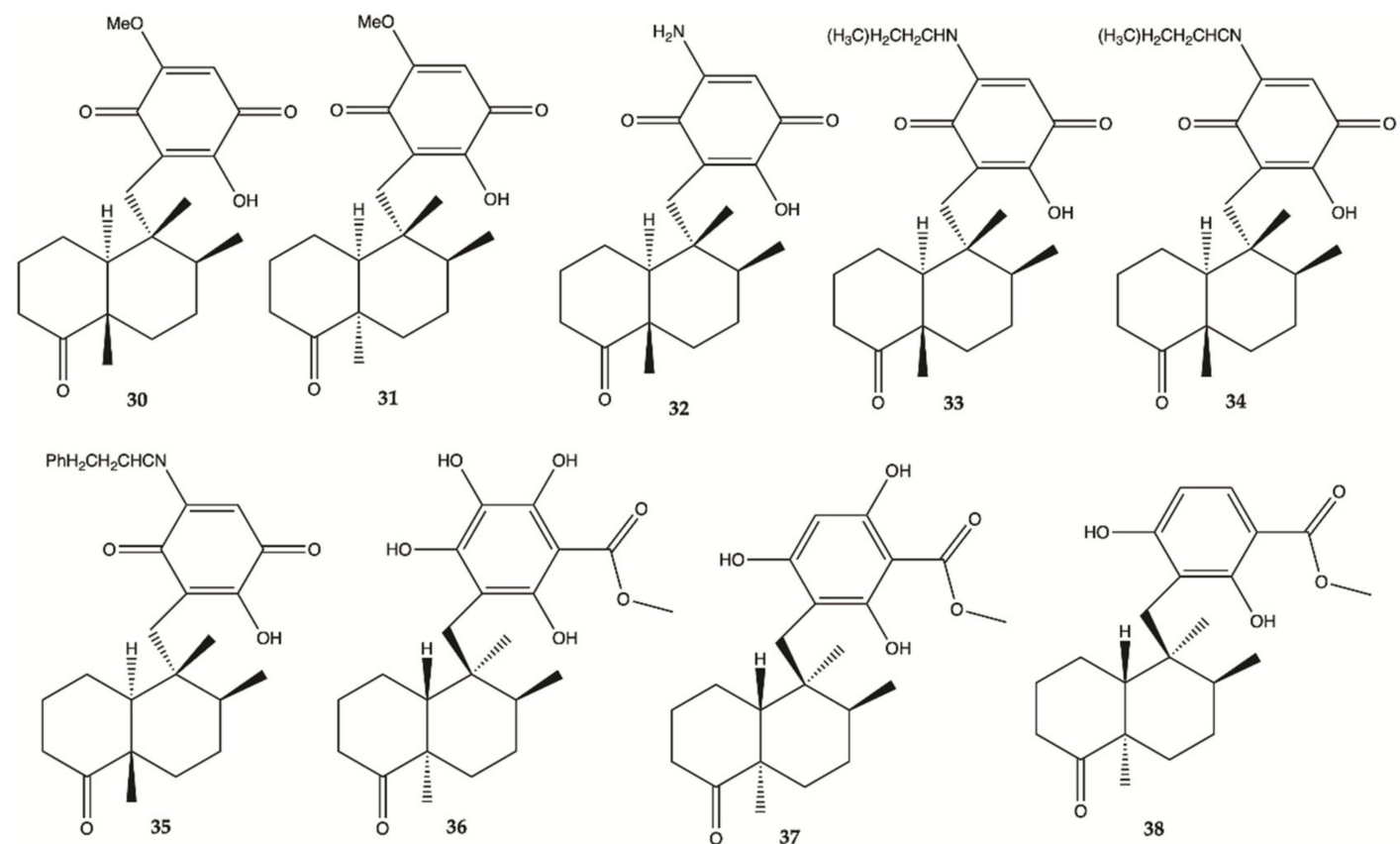

Figure 14. Sesquiterpenes 30-38 isolated from extracts of the Hawaiian marine sponge Dactylospongia elegans [53].

Compound 39 was isolated from a marine sponge Haliclona tubifera, which is abundant species on the southern Brazilian coast (Figure 15). This compound showed a cytotoxic effect in human glioma cell lines (U87MG), with a value lower than $\mathrm{IC}_{50}<15 \mu \mathrm{g} / \mathrm{mL}$ [54].<smiles>CCCCCCCCCC/C=C\[C@H](O)CC[C@H](O)[C@H](N)CO</smiles>

Figure 15. Sphingosine 39 isolated from a marine sponge Haliclona tubifera [54].

Overall, marine sponges from Brazilian, Hawaiian, Caribbean and South Pacific coasts were explored for their ability to produce secondary metabolites with anti-glioma activity. Concerning alkaloids, compound 28 was the most active. Plakortide (compound 29) has a core potent and effective against glioma cell lines. Considering sesquiterpenes, compounds 32 and 36 showed the highest potency. The only sphingosine (compound 39) isolated from marine sponges showed high activity against glioma cells.

\subsection{Marine Corals}

Seven compounds extracted from marine corals showed activity against human malignant glioma cells.

Compounds 40-46 (Figure 16) are derived from specimens of Caribbean Gorgonian Octocoral Eunicea succinea. These compounds were encoded and examined blindly for their relative cytotoxicity against human malignant glioma cells U87MG and U373MG. The cells were treated with each compound from 0 to $100 \mathrm{~mol} / \mathrm{L}$ for $72 \mathrm{~h}$ and viability was determined using the 3-(4,5-dimethylthiazol-2-yl)-2,5-diphenyltetrazolium bromide assay. Compound 40 was stable for at least several months and was the most potent compound exhibiting $\mathrm{IC}_{50}$ values of $5.1 \mathrm{~mol} / \mathrm{L}$ for U87MG cells and $6.9 \mathrm{~mol} / \mathrm{L}$ for U373MG cells. This $\mathrm{IC}_{50}$ range is compatible with that of cisplatin, which is in the range of 5 to $10 \mathrm{~mol} / \mathrm{L}$ for these types of cells. These results lead to focus on mechanism of action of compound 40 [52]. Compound 40 induced interruption of the G2-M cell cycle and apoptosis via the mitochondrial pathway. This compound was found to increase the phosphorylated JNK by $>50 \%$ in both U87MG and U373MG cells. A specific JNK inhibitor, SP600125, inhibited 
apoptosis, confirming the involvement of the JNK pathway in cell death by compoundinduced apoptosis. In addition, seven days of daily intratumor injections of compound $\mathbf{4 0}$ significantly suppressed the growth of malignant glioma xenografts [52].<smiles>C/C=C1\C(=O)O[C@@H]([C@H](O)[C@@H](C)CC)C1C[C@@H]1O[C@]1(C)CC/C=C(/C)CC</smiles>

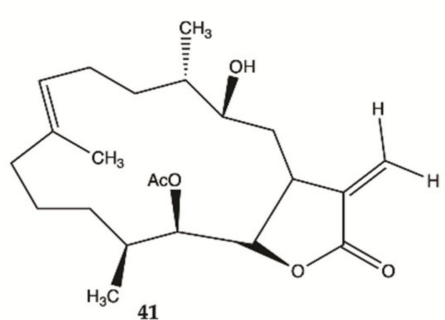

41<smiles></smiles><smiles>C=C1C(=O)CC1CC/C(C)=C/CC/C(C)=C\CC[C@](C)(O)[C@H]1CC1=O</smiles><smiles>C=C(OC(=O)O)[C@H](CC)CC/C(C)=C/CC/C(C)=C\CC[C@@]1(C)O[C@@H]1C</smiles><smiles>C=C(C)[C@H]1CC/C(C)=C/CC[C@]2(C)CC(=O)/C=C(/C=O)CC[C@@H](C1)O2</smiles><smiles>C=C(C)C(CC)CC/C(C)=C/CC[C@@]1(C)O[C@H]1CC/C(=C\C(=O)OC)CO[Na]</smiles>

Figure 16. Polyketides 40-46 isolated from Caribbean Octocoral Eunicea succinea [52].

\subsection{Marine Fungi}

In 2018, one alkaloid with antiproliferative activity against human glioma cells was isolated from a marine fungus strain ZZ380 isolated from a wild crab [55].

The proliferation of glioma U87MG, U251, SHG44 and C6 cells in the presence of penicipyrroether alkaloid (47, Figure 17) was assayed by SRB assay. Compound 47 showed potent activity in inhibiting the proliferation of different glioma cells with $\mathrm{IC}_{50}$ values of 1.64 e $5.50 \mu \mathrm{M}$ for U87MG and U251 cells, respectively [55].

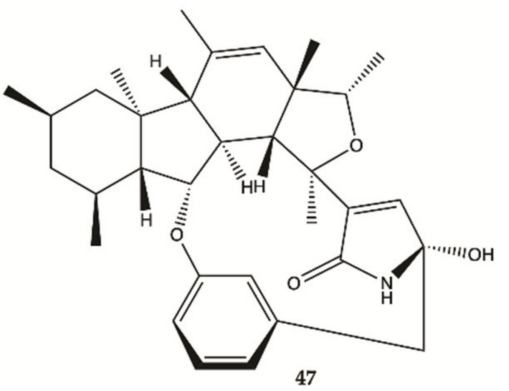

Figure 17. Alkaloid 47 isolated from marine fungus strain ZZ380 [55].

\subsection{Cucumbers}

Sulfated saponins were isolated from sea cucumber Holothuria moebii Ludwig, a species of sea cucumbers of the Holothuriidae family. For the first time, sulfated saponins 48-50 (Figure 18) were shown to have potent activity in suppressing the proliferation of glioma cells (C6 glioma cells, U87MG, U251 and SHG44 cells). This study also uncovered that sulfated saponin 48 could have a unique antitumor mechanism by selectively targeting multiple glioma metabolic regulators of glycolysis and glutaminolysis, hexokinase 2 (HK2), 6-phosphofructo-2-kinase/2,6-bisphosphatase 3 (PFKFB3), pyruvate kinase (PKM2) and glutaminase (GLS). It has been revealed that these metabolic regulators are related to the 
tumorigenesis of gliomas [56]. Saponin 48 had no significant effect on the expression levels of HK2, PFKFB3, PKM2 and GLS in HA.

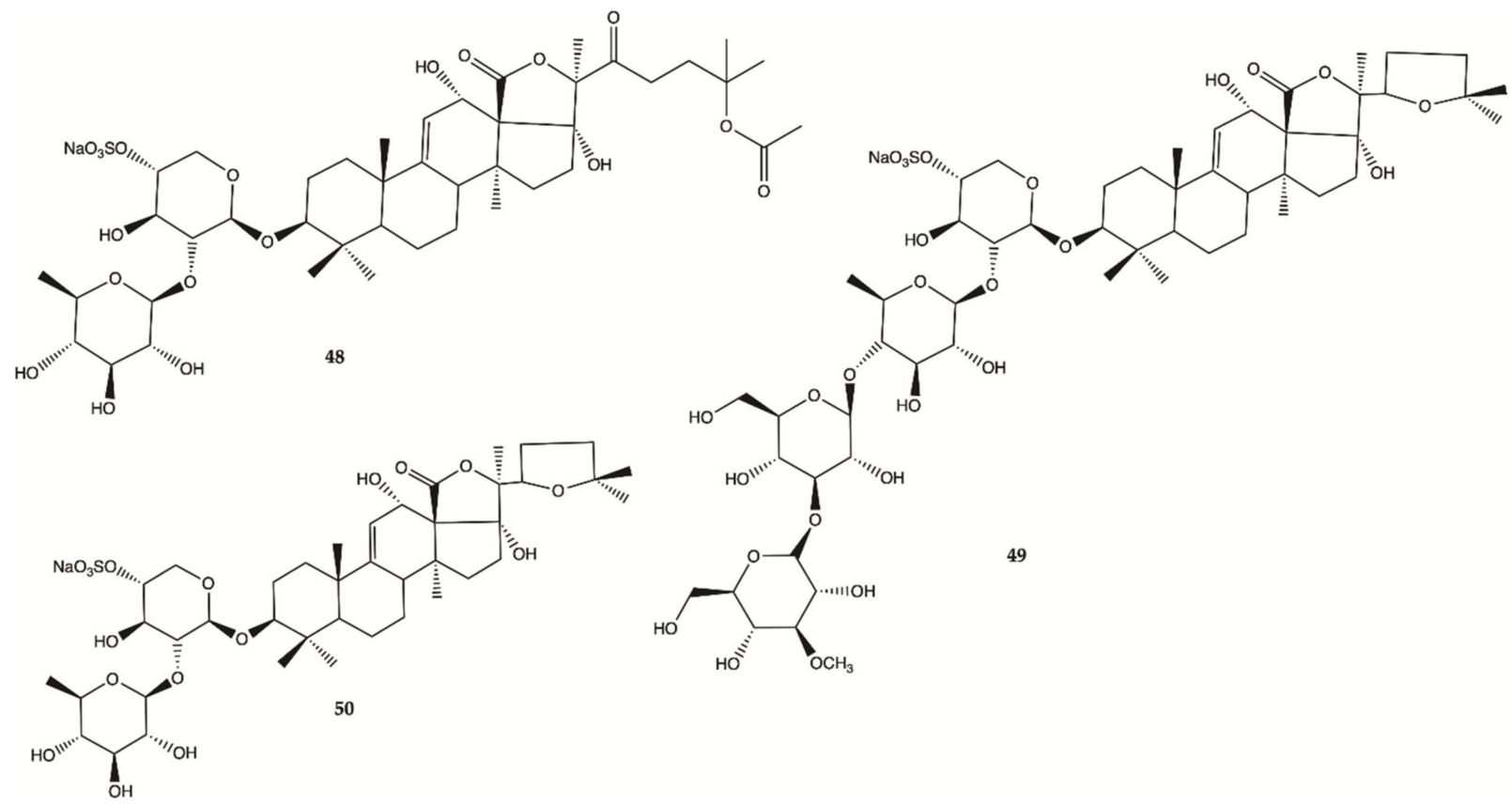

Figure 18. Sulfated saponins 48-50 isolated from Cucumber Holothuria moebii [56].

\subsection{Crustaceans and Fishes}

Astaxanthine (51, Figure 18) is a red pigment found in crustaceans and fish that occurs naturally in shrimp, crab and salmon, and is also synthesized in Haematococcus pluvialis. Adonixanthin (52) is an intermediate product of astaxanthin (Figure 19) [57]. A cell viability assay was performed using the murine GBM cell lines GL261 and human GBM cell line U251MG cells. In GL261 cells, compounds $\mathbf{5 1}$ and 52 suppressed cell viability at concentration of more than 5 and $0.1 \mu \mathrm{M}$. In U251MG cells, compounds 51 and 52 suppressed cell viability at concentrations of more than 1 and $0.1 \mu \mathrm{M}$.<smiles>CC1=C(/C=C/C=C/C=C/C=C/C=C/C=C(C)/C=C/C=C(C)/C=C/C2=C(C)C(=O)[C@@H](O)CC2(C)C)C(C)(C)C[C@H](O)C1=O</smiles><smiles>CC1=C(/C=C/C(C)=C/C=C/C(C)=C/C=C/C=C(C)/C=C/C=C(C)/C=C/C2=C(C)C(=O)[C@@H](O)CC2(C)C)C(C)(C)C[C@H](O)C1</smiles>

Figure 19. Astaxanthin (51) Adonixanthin (52) isolated from a red pigment [57]. 
These two compounds inhibited both cell proliferation and migration in human and mouse glioma cells. Both were found to reduce the expression of phopharylated ERK1/2 and phosphorylated Akt [57].

\section{ADME Properties}

Effective treatment for glioma tumors is limited by the presence of the BBB. The high molecular weight of most of these marine natural products may limit BBB permeability. In this direction, we have performed in silico predictions of some pharmacokinetic parameters of the nearly fifty marine compounds presented in this review (Table 1). The development of drugs involves the assessment of absorption, distribution, metabolism and excretion (ADME), parameters that must be evaluated as early as possible that process. In this context, computational models are very good approaches, to provide access to a set of rapid, yet robust predictive models, for physical-chemical, pharmacokinetic, pharmacokinetic properties and compatibility with medicinal chemistry requirements [58]. To complement the information disclosed, the pharmacokinetic parameters were evaluated in this document using the SWISSADME platform [59].

Table 1. Pharmacokinetic parameters of marine compounds that are described in this review.

\begin{tabular}{|c|c|c|c|c|c|}
\hline Compounds & $\begin{array}{c}\text { Molecular } \\
\text { Weight (g/mol) }\end{array}$ & $\log P$ & $\begin{array}{c}\text { H-Bond } \\
\text { Acceptors-Donors } \\
10-5\end{array}$ & $\begin{array}{l}\text { Lipinsky } \\
\text { Rules }\end{array}$ & $\begin{array}{c}\text { BBB } \\
\text { Permeability }\end{array}$ \\
\hline 1 & 298.25 & 1.32 & $6-3$ & Yes & No \\
\hline 2 & 304.29 & 2.01 & $6-2$ & Yes & No \\
\hline 3 & 329.35 & 1.65 & $6-4$ & Yes & No \\
\hline 4 & 228.25 & 1.25 & $4-1$ & Yes & No \\
\hline 5 & 254.33 & 2.70 & $3-0$ & Yes & Yes \\
\hline 6 & 168.19 & 1.76 & $2-0$ & Yes & No \\
\hline 7 & 299.29 & 3.61 & $0-0$ & No & No \\
\hline 8 & 372.28 & 1.78 & $9-6$ & No & No \\
\hline 9 & 242.25 & 0.58 & $7-3$ & Yes & No \\
\hline 10 & 644.92 & 6.73 & $5-2$ & No & No \\
\hline 11 & 610.78 & 4.43 & $10-5$ & No & No \\
\hline 12 & 604.81 & 5.00 & $8-3$ & No & No \\
\hline 13 & 620.81 & 4.74 & $9-4$ & No & No \\
\hline 14 & 674.90 & 5.89 & $9-2$ & No & No \\
\hline 15 & 1243.45 & 5.80 & $18-5$ & No & No \\
\hline 16 & 1258.44 & -0.33 & $19-5$ & No & No \\
\hline 17 & 1259.45 & 5.14 & $19-6$ & No & No \\
\hline 18 & 748.77 & 4.27 & $14-5$ & No & No \\
\hline 19 & 734.74 & 4.23 & $14-6$ & No & No \\
\hline 20 & 297.35 & 1.55 & $5-3$ & Yes & No \\
\hline
\end{tabular}


Table 1. Cont.

\begin{tabular}{|c|c|c|c|c|c|}
\hline Compounds & $\begin{array}{c}\text { Molecular } \\
\text { Weight (g/mol) }\end{array}$ & $\log P$ & $\begin{array}{c}\text { H-Bond } \\
\text { Acceptors-Donors } \\
10-5\end{array}$ & $\begin{array}{l}\text { Lipinsky } \\
\text { Rules }\end{array}$ & $\begin{array}{c}\text { BBB } \\
\text { Permeability }\end{array}$ \\
\hline 21 & 297.35 & 1.53 & $5-3$ & Yes & No \\
\hline 22 & 298.29 & 2.26 & $5-3$ & Yes & No \\
\hline 23 & 769.92 & 0.00 & $11-4$ & No & No \\
\hline 24 & 579.64 & 0.00 & $11-0$ & No & No \\
\hline 25 & 889.03 & 1.43 & $10-1$ & $\mathrm{No}$ & No \\
\hline 26 & 436.6 & 4.46 & $2-2$ & No & No \\
\hline 27 & 464.73 & 4.49 & $3-1$ & No & Yes \\
\hline 28 & 426.72 & 4.85 & $2-2$ & $\mathrm{No}$ & No \\
\hline 29 & 338.48 & 3.83 & $4-1$ & Yes & Yes \\
\hline 30 & 360.44 & 2.91 & $5-1$ & Yes & No \\
\hline 31 & 360.44 & 2.72 & $5-1$ & Yes & No \\
\hline 32 & 345.43 & 2.15 & $4-2$ & Yes & No \\
\hline 33 & 401.54 & 3.51 & $4-2$ & Yes & No \\
\hline 34 & 415.57 & 3.67 & $4-2$ & Yes & No \\
\hline 35 & 449.58 & 3.67 & $4-2$ & Yes & No \\
\hline 36 & 392.49 & 2.45 & $6-3$ & Yes & No \\
\hline 37 & 376.49 & 2.48 & $5-2$ & Yes & No \\
\hline 38 & 360.49 & 3.06 & $4-1$ & Yes & Yes \\
\hline 39 & 315.49 & 3.88 & $4-4$ & Yes & No \\
\hline 40 & 376.49 & 3.30 & $5-0$ & Yes & Yes \\
\hline 41 & 378.50 & 3.31 & $5-1$ & Yes & Yes \\
\hline 42 & 516.62 & 4.29 & $8-2$ & No & No \\
\hline 43 & 318.45 & 3.31 & $3-1$ & Yes & Yes \\
\hline 44 & 332.48 & 3.63 & $3-0$ & Yes & Yes \\
\hline 45 & 330.46 & 3.00 & $3-0$ & Yes & Yes \\
\hline 46 & 374.51 & 4.07 & $4-0$ & No & Yes \\
\hline 47 & 517.66 & 3.41 & $5-2$ & No & No \\
\hline 48 & 925.99 & 0.00 & $19-6$ & No & No \\
\hline 49 & 1221.30 & 4.52 & $20-7$ & No & No \\
\hline 50 & 882.98 & 0.00 & $17-6$ & No & No \\
\hline 51 & 568.79 & 6.14 & $4-2$ & No & No \\
\hline 52 & 582.85 & 6.83 & $3-2$ & No & No \\
\hline TMZ & 194.15 & 1.29 & $5-1$ & Yes & No \\
\hline
\end{tabular}

Based on the analyses of Table 1 , it may be concluded that more than half of the isolated marine compounds (1-6, 9, 20-22, 29-41, 43-46) follow Lipinski rules [60], but only ten $(5,27,29,38,40,41,43-46)$ are predicted to have high BBB permeability.

\section{Nanotechnology to Improve Anti-Glioblastoma Drugs}

Conventional treatments, normally, do not guarantee the necessary distribution of the drug to the tumor site, therefore hydrophilic drugs and/or low molecular weight drugs 
generally do not accumulate until reaching therapeutic levels in cancerous tissues, being categorized by a small circulation half-life [61]. Good drug therapy is not just related only to the molecule, but also to the delivery way [62]. Development of glioma-specific nanoparticles (NPs) has been an area of intense research over the past years. These drug delivery systems (DDS) have the capacity to be loaded with therapeutic agents and functionalized with different ligands (e.g., transferrin, chlorotoxin (CTX), hyaluronic acid) that allow targeting and crossing the BBB $[63,64]$. Thus, in this strategy, the ability to cross the BBB does not depend on the structure of the drug, but on the physicochemical properties of the $\mathrm{NP}$, which can be improved. NP play an important role in the release of drugs through the BBB by passive diffusion, which results in a high concentration gradient between the blood and the brain and have the ability to diffuse in the vasculature with leakage of tumor tissues due to the increase in permeability and retention effect $[64,65]$. The deficient lymphatic drainage allows the NP to reach concentrations much higher than their concentrations in plasma [66]. NP designed for drug delivery to the brain needs to meet certain essential requirements to be more effective, such as reduced toxicity and biodegradability, prolonged circulation time, no aggregation in the blood, good encapsulation efficiency and the ability to cross the BBB [61].

Different types of nanotransporters were already applied to improve permeability and efficacy of TMZ or other innovative drugs on glioma treatment [67] as follows.

TMZ was successfully encapsulated with different functionalized NPs such as: transferrin-functionalized liposome loaded with TMZ and the bromodomain inhibitor JQ1 [68], biotin-functionalized chitosan conjugated with TMZ and surface-bound CTX ligand [69], poly(lactide-co-glycolide) (PLGA)-NP- monoclonal antibody functionalized with an OX26 mAbs [70], mesopore silica nanoparticles [71], gold-coated nanofibers [72] and magnetite NP where TMZ was loaded and incorporated into the synthesized polyurethane based on poly ( $\varepsilon$-caprolactone diol) [73]. DOX was also tested with different NPs for glioma such as: magnetic silica NPs- functionalized with poly transferrin (D, L-lactic-co-glycolic acid) [74], biocompatible magnetic iron oxide NP stabilized with trimethoxysilylpropylethylenediamine triacetic acid [75], polymeric micelle obtained from aspartic acid from poly (ethylene glycol)-b-poly (aspartic acid) block copolymer [76] and a surface-modified liposomal formulation with proteolytically stable peptides, CDX and c(RGDyK) [77]. Paclitaxel was encapsulated in an NP composed of PLGA [78] and in micelles-loaded with transferrin [79]. The anticancer efficacy of Asiatic acid (a pentacyclic triterpene, that is one of the active components of a plant, Centella Asiatica) was loaded into solid lipidic NP [80]. A potent anti-glioma synthetic xanthone derivative was synthesized and proliposomes and liposomes were developed as drug carriers [81].

It may be suggested that some of these nanotransporters may be successfully applied to improve the permeability of some of these promising anti-glioma marine compounds.

\section{Conclusions}

This review summarized the compounds from marine sources found in the last decade with activity against the growth of glioma cells. Nearly fifty compounds were isolated from anemone, brown, red and green seaweeds, invertebrates, sponges, corals, fungi and crustaceos. It was possible to observe that most compounds were isolated from marine sponges $(27 \%)$, followed by seaweeds $(15 \%)$ and marine bacteria and marine corals (both with 13\%) (Figure 20). A high chemical diversity was found: anthraquinones, chromones, peptides, pyrazolidines, sesquiterpenes, tanines, saccharides, carotenoids, Bafilomycins, Actinomycins, Fradimicins, Streptoglutarimides, alkaloids and saponins. From these, sesquiterpenes $(19 \%)$, alkaloids $(13 \%)$ and polyketides $(13 \%)$ were the most commonly described compounds with antiproliferative activity (Figure 21). 


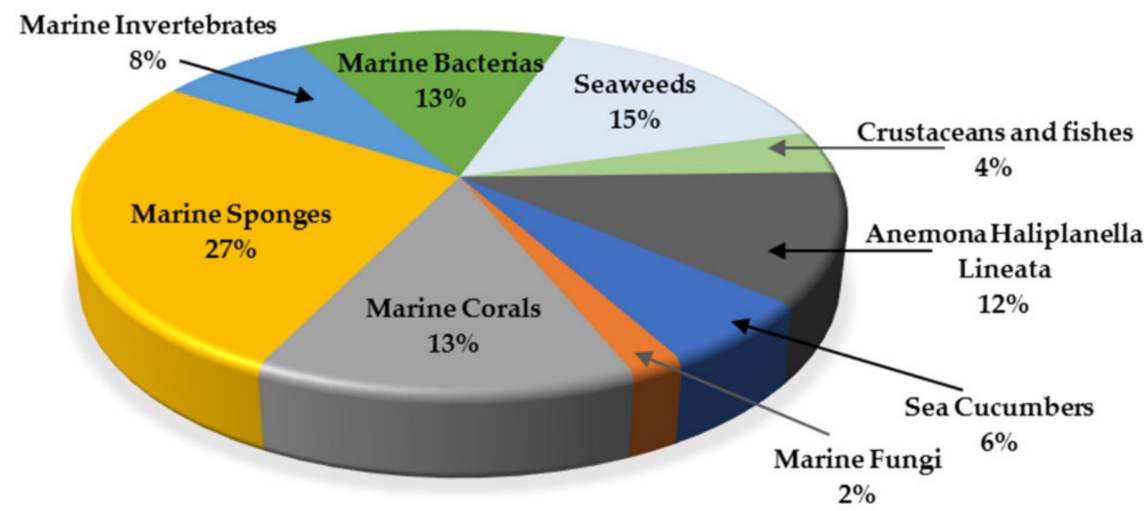

Figure 20. Marine organisms as sources of anti-glioma compounds.

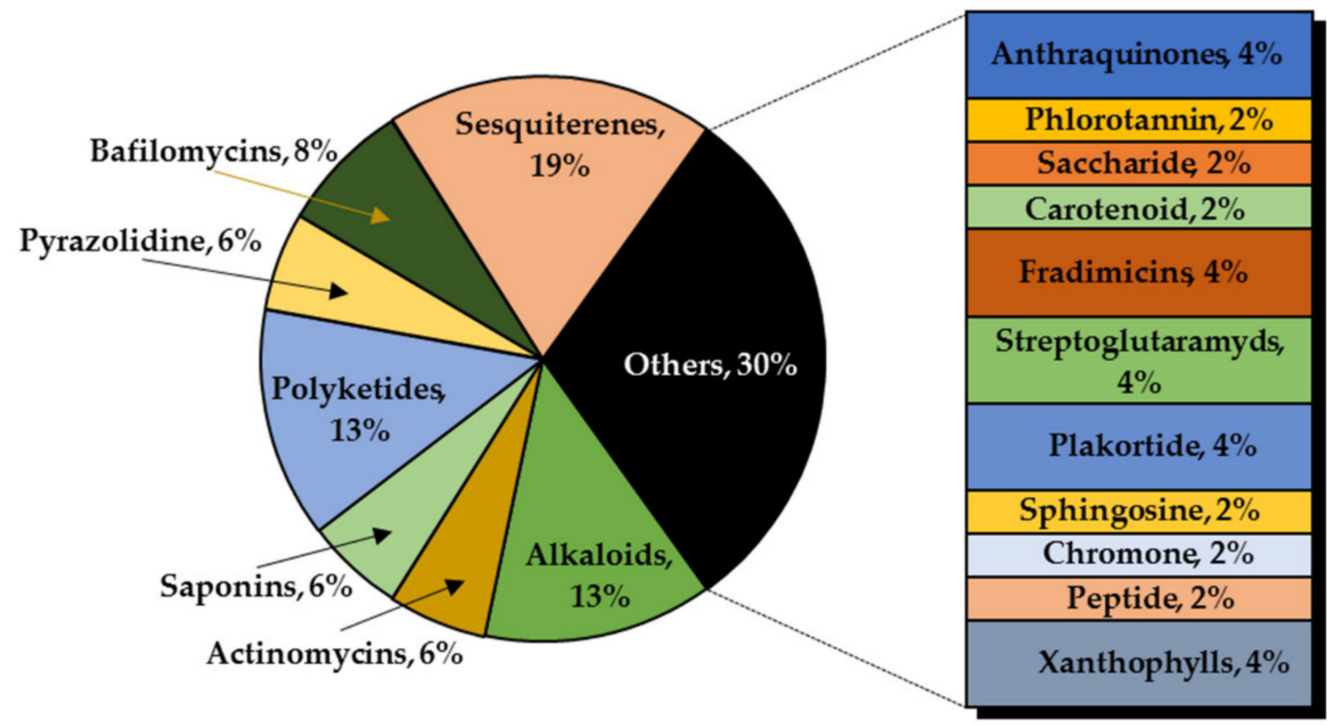

Figure 21. Most significant chemical classes of anti-glioma compounds.

The majority of studies have only conducted as preliminary on drug discovery processes involving in vitro screening on glioma cell lines, including, T98G, U87MG, SHG44, U251MG, U373MG, C6 among others. None have already reached advanced stages of preclinical development with proven efficacy in vivo. However, the mechanisms of action of some compounds have been elucidated, including: (i) the decrease of levels of expression of various metabolic enzymes overexpressed in the glioma, namely glycolytic enzymes (HK2, PFKFB3, PKM2 and LDH5) by compounds 1, 2,15 and 48 and enzymes involved in glutaminolysis (GLS) by compounds 15 and 48 , and in lipogenesis (FASN) by compound 15; (ii) inhibition of the AKT pathway, from which proteins are highly expressed in tumors with a worse prognosis, by compound 7; (iii) inhibition of caspase $3 / 7$ activity and increase of LDH activity, leading to apoptosis by compound 22; (iv) inactivation of EGFR and the PI3K-AKT signaling pathway by compounds $23-25$, leading to cell death; (v) and interruption of the G2-M cell cycle and mitochondrial apoptosis by compound 40 .

From the nearly fifty marine compounds, only ten $(5,27,29,38,40,41,43-46)$ have potential to cross $\mathrm{BBB}$, being the pyrazolidene 5 , isolated from an anemone, the most potent compound $\left(\mathrm{IC}_{50}=0.5\right.$ to $\left.3.0 \mu \mathrm{M}\right)$ followed by the plakortide $29\left(\mathrm{IC}_{50}=4.0 \mu \mathrm{M}\right)$ and the polyketide $38\left(\mathrm{IC}_{50}=4.1 \mu \mathrm{M}\right)$, both isolated from sponges and by the polyketide 40 $\left(\mathrm{IC}_{50}=5.1\right.$ to $\left.6.9 \mu \mathrm{M}\right)$, isolated from corals.

Due to numerous advantages of the above-mentioned DDS, they can help decreasing toxicity and providing greater BBB permeability and effectiveness within the brain. It can be expected that some of the most promising compounds derived from marine sources can be applied in the future in conjunction with some of the new DDS. On the other hand, some 
of the presented marine compounds may work as models for the synthesis of simplified analogs in a near future.

Author Contributions: Conceptualization, M.C.-d.-S. and M.P.; methodology, A.A.; validation, A.A.; formal analysis, P.C. and D.F.; investigation, A.A.; writing —original draft preparation, A.A.; writingreview and editing, M.C.-d.-S., P.C., M.P. and D.F.; supervision, M.C.-d.-S., P.C. and D.F.; funding acquisition, D.F., M.C.-d.-S. and M.P. All authors have read and agreed to the published version of the manuscript.

Funding: This research was funded by FCT (Foundation for Science and Technology) under the strategic funding, grant number UIDB/04423/2020, UIDP/04423/2020 (Group of Natural Products and Medicinal Chemistry_CIIMAR) and UID/Multi/04378/2019 (Molecular Biosciences UnitUCIBIO) as well as supported by the Norte Portugal Regional Operational Programme (NORTE 2020), under the PORTUGAL 2020 Partnership Agreement and through the ERDF, as a result of the project ATLANTIDA, grant number NORTE-01-0145-FEDER-000040 and by IINFACTS, grant number CHIRALBIOACTIVE-PI-3RL-IINFACTS-2019 and CHIRALSINTE-SE_APSFCT_IINFACTS_2021. A.A. also acknowledges FCT for the PhD scholarship SFRH/BD/144607/2019.

Institutional Review Board Statement: Not applicable.

Informed Consent Statement: Not applicable.

Data Availability Statement: Not applicable.

Conflicts of Interest: The authors declare no conflict of interest.

\section{References}

1. World Health Organization. Cancer. Available online: https://www.who.int/news-room/fact-sheets/detail/cancer (accessed on 18 October 2020).

2. Poon, M.T.C.; Sudlow, C.L.M.; Figueroa, J.D.; Brennan, P.M. Longer-term ( $\geq 2$ years) survival in patients with glioblastoma in population-based studies pre- and post-2005: A systematic review and meta-analysis. Sci. Rep. 2020, 10, 11622. [CrossRef] [PubMed]

3. Louis, D.N.; Perry, A.; Reifenberger, G.; von Deimling, A.; Figarella-Branger, D.; Cavenee, W.K.; Ohgaki, H.; Wiestler, O.D.; Kleihues, P.; Ellison, D.W. The 2016 World Health Organization Classification of Tumors of the Central Nervous System: A summary. Acta Neuropathol. 2016, 131, 803-820. [CrossRef]

4. Hanif, F.; Muzaffar, K.; Perveen, K.; Malhi, S.M.; Simjee, S.U. Glioblastoma Multiforme: A Review of its Epidemiology and Pathogenesis through Clinical Presentation and Treatment. Asian Pac. J. Cancer Prev. 2017, 18, 3-9. [CrossRef]

5. Svec, R.L.; Furiassi, L.; Skibinski, C.G.; Fan, T.M.; Riggins, G.J.; Hergenrother, P.J. Tunable Stability of Imidazotetrazines Leads to a Potent Compound for Glioblastoma. ACS Chem. Biol. 2018, 13, 3206-3216. [CrossRef]

6. Martins, S.M.; Sarmento, B.; Nunes, C.; Lucio, M.; Reis, S.; Ferreira, D.C. Brain targeting effect of camptothecin-loaded solid lipid nanoparticles in rat after intravenous administration. Eur. J. Pharm. Biopharm. Off. J. Arbeitsgem. Pharm. Verfahrenstech. e.V. 2013, 85, 488-502. [CrossRef] [PubMed]

7. Vieira de Castro, J.; Gomes, E.D.; Granja, S.; Anjo, S.I.; Baltazar, F.; Manadas, B.; Salgado, A.J.; Costa, B.M. Impact of mesenchymal stem cells' secretome on glioblastoma pathophysiology. J. Transl. Med. 2017, 15, 200. [CrossRef]

8. Goncalves, C.S.; Vieira de Castro, J.; Pojo, M.; Martins, E.P.; Queiros, S.; Chautard, E.; Taipa, R.; Pires, M.M.; Pinto, A.A.; Pardal, F.; et al. WNT6 is a novel oncogenic prognostic biomarker in human glioblastoma. Theranostics 2018, 8, 4805-4823. [CrossRef] [PubMed]

9. Mrugala, M.M. Advances and challenges in the treatment of glioblastoma: A clinician's perspective. Discov. Med. 2013, 15, 221-230.

10. Yan, H.; Wang, L.; Wang, J.; Weng, X.; Lei, H.; Wang, X.; Jiang, L.; Zhu, J.; Lu, W.; Wei, X.; et al. Two-order targeted brain tumor imaging by using an optical/paramagnetic nanoprobe across the blood brain barrier. ACS Nano 2012, 6, 410-420. [CrossRef]

11. Reardon, D.A.; Wen, P.Y. Therapeutic advances in the treatment of glioblastoma: Rationale and potential role of targeted agents. Oncologist 2006, 11, 152-164. [CrossRef]

12. Moody, C.L.; Wheelhouse, R.T. The medicinal chemistry of imidazotetrazine prodrugs. Pharmaceuticals 2014, 7, 797-838. [CrossRef]

13. Scott, J.; Tsai, Y.Y.; Chinnaiyan, P.; Yu, H.H. Effectiveness of radiotherapy for elderly patients with glioblastoma. Int. J. Radiat. Oncol. Biol. Phys. 2011, 81, 206-210. [CrossRef]

14. Chang, J.E.; Khuntia, D.; Robins, H.I.; Mehta, M.P. Radiotherapy and radiosensitizers in the treatment of glioblastoma multiforme. Clin. Adv. Hematol. Oncol. 2007, 5, 894-902.

15. Braga, C.; Vaz, A.R.; Oliveira, M.C.; Matilde Marques, M.; Moreira, R.; Brites, D.; Perry, M.J. Targeting gliomas with triazene-based hybrids: Structure-activity relationship, mechanistic study and stability. Eur. J. Med. Chem. 2019, 172, 16-25. [CrossRef] 
16. Yang, B.; Li, X.; He, L.; Zhu, Y. Computer-aided design of temozolomide derivatives based on alkylglycerone phosphate synthase structure with isothiocyanate and their pharmacokinetic/toxicity prediction and anti-tumor activity in vitro. Biomed. Rep. 2018, 8 , 235-240. [CrossRef] [PubMed]

17. Yang, Z.; Wei, D.; Dai, X.; Stevens, M.F.G.; Bradshaw, T.D.; Luo, Y.; Zhang, J. C8-Substituted Imidazotetrazine Analogs Overcome Temozolomide Resistance by Inducing DNA Adducts and DNA Damage. Front. Oncol. 2019, 9. [CrossRef]

18. Fernandes, G.F.d.S.; Fernandes, B.C.; Valente, V.; dos Santos, J.L. Recent advances in the discovery of small molecules targeting glioblastoma. Eur. J. Med. Chem. 2019, 164, 8-26. [CrossRef] [PubMed]

19. Filbin, M.G.; Dabral, S.K.; Pazyra-Murphy, M.F.; Ramkissoon, S.; Kung, A.L.; Pak, E.; Chung, J.; Theisen, M.A.; Sun, Y.; Franchetti, Y.; et al. Coordinate activation of Shh and PI3K signaling in PTEN-deficient glioblastoma: New therapeutic opportunities. Nat. Med. 2013, 19, 1518-1523. [CrossRef] [PubMed]

20. Abeyrathna, P.; Su, Y. The critical role of Akt in cardiovascular function. Vascul. Pharmacol. 2015, 74, 38-48. [CrossRef] [PubMed]

21. Beyer, C.F.; Zhang, N.; Hernandez, R.; Vitale, D.; Lucas, J.; Nguyen, T.; Discafani, C.; Ayral-Kaloustian, S.; Gibbons, J.J. TTI-237: A novel microtubule-active compound with in vivo antitumor activity. Cancer Res. 2008, 68, 2292-2300. [CrossRef] [PubMed]

22. Kitambi, S.S.; Toledo, E.M.; Usoskin, D.; Wee, S.; Harisankar, A.; Svensson, R.; Sigmundsson, K.; Kalderén, C.; Niklasson, M.; Kundu, S.; et al. RETRACTED: Vulnerability of Glioblastoma Cells to Catastrophic Vacuolization and Death Induced by a Small Molecule. Cell 2014, 157, 313-328. [CrossRef]

23. Sestito, S.; Daniele, S.; Nesi, G.; Zappelli, E.; Di Maio, D.; Marinelli, L.; Digiacomo, M.; Lapucci, A.; Martini, C.; Novellino, E.; et al. Locking PDK1 in DFG-out conformation through 2-oxo-indole containing molecules: Another tools to fight glioblastoma. Eur. J. Med. Chem. 2016, 118, 47-63. [CrossRef]

24. Cherry, A.E.; Haas, B.R.; Naydenov, A.V.; Fung, S.; Xu, C.; Swinney, K.; Wagenbach, M.; Freeling, J.; Canton, D.A.; Coy, J.; et al. ST-11: A New Brain-Penetrant Microtubule-Destabilizing Agent with Therapeutic Potential for Glioblastoma Multiforme. Mol. Cancer Ther. 2016, 15, 2018-2029. [CrossRef] [PubMed]

25. Overmeyer, J.H.; Young, A.M.; Bhanot, H.; Maltese, W.A. A chalcone-related small molecule that induces methuosis, a novel form of non-apoptotic cell death, in glioblastoma cells. Mol. Cancer 2011, 10, 69. [CrossRef] [PubMed]

26. Robinson, M.W.; Overmeyer, J.H.; Young, A.M.; Erhardt, P.W.; Maltese, W.A. Synthesis and evaluation of indole-based chalcones as inducers of methuosis, a novel type of nonapoptotic cell death. J. Med. Chem. 2012, 55, 1940-1956. [CrossRef]

27. Sestito, S.; Nesi, G.; Daniele, S.; Martelli, A.; Digiacomo, M.; Borghini, A.; Pietra, D.; Calderone, V.; Lapucci, A.; Falasca, M.; et al. Design and synthesis of 2-oxindole based multi-targeted inhibitors of PDK1/Akt signaling pathway for the treatment of glioblastoma multiforme. Eur. J. Med. Chem. 2015, 105, 274-288. [CrossRef]

28. Daniele, S.; Sestito, S.; Pietrobono, D.; Giacomelli, C.; Chiellini, G.; Di Maio, D.; Marinelli, L.; Novellino, E.; Martini, C.; Rapposelli, S. Dual Inhibition of PDK1 and Aurora Kinase A: An Effective Strategy to Induce Differentiation and Apoptosis of Human Glioblastoma Multiforme Stem Cells. ACS Chem. Neurosci. 2017, 8, 100-114. [CrossRef] [PubMed]

29. Mateos, R.; Pérez-Correa, J.R.; Domínguez, H. Bioactive Properties of Marine Phenolics. Mar. Drugs 2020, 18, 501. [CrossRef]

30. Stien, D. Marine Microbial Diversity as a Source of Bioactive Natural Products. Mar. Drugs 2020, 18, 215. [CrossRef]

31. Martins, B.T.; Correia da Silva, M.; Pinto, M.; Cidade, H.; Kijjoa, A. Marine natural flavonoids: Chemistry and biological activities. Nat. Prod. Res. 2019, 33, 3260-3272. [CrossRef]

32. Suleria, H.A.R.; Gobe, G.; Masci, P.; Osborne, S.A. Marine bioactive compounds and health promoting perspectives; innovation pathways for drug discovery. Trends Food Sci. Technol. 2016, 50, 44-55. [CrossRef]

33. Carroll, A.R.; Copp, B.R.; Davis, R.A.; Keyzers, R.A.; Prinsep, M.R. Marine natural products. Nat. Prod. Rep. 2021, $38,362-413$. [CrossRef]

34. Honek, J.; Efferth, T. Marine Compounds. In Biodiversity, Natural Products and Cancer Treatment; World Scientific: Singapore, 2013; pp. 209-250.

35. Wali, A.F.; Majid, S.; Rasool, S.; Shehada, S.B.; Abdulkareem, S.K.; Firdous, A.; Beigh, S.; Shakeel, S.; Mushtaq, S.; Akbar, I.; et al. Natural products against cancer: Review on phytochemicals from marine sources in preventing cancer. Saudi Pharm. J. 2019, 27, 767-777. [CrossRef] [PubMed]

36. Ruiz-Torres, V.; Encinar, J.A.; Herranz-López, M.; Pérez-Sánchez, A.; Galiano, V.; Barrajón-Catalán, E.; Micol, V. An Updated Review on Marine Anticancer Compounds: The Use of Virtual Screening for the Discovery of Small-Molecule Cancer Drugs. Molecules 2017, 22, 1037. [CrossRef]

37. Zhang, X.; Ye, X.; Chai, W.; Lian, X.-Y.; Zhang, Z. New Metabolites and Bioactive Actinomycins from Marine-Derived Streptomyces sp. ZZ338. Mar. Drugs 2016, 14, 181. [CrossRef]

38. Ye, X.; Anjum, K.; Song, T.; Wang, W.; Liang, Y.; Chen, M.; Huang, H.; Lian, X.-Y.; Zhang, Z. Antiproliferative cyclodepsipeptides from the marine actinomycete Streptomyces sp. P11-23B downregulating the tumor metabolic enzymes of glycolysis, glutaminolysis, and lipogenesis. Phytochemistry 2017, 135, 151-159. [CrossRef] [PubMed]

39. Anjum, K.; Bi, H.; Chai, W.; Lian, X.-Y.; Zhang, Z. Antiglioma pseurotin A from marine Bacillus sp. FS8D regulating tumour metabolic enzymes. Nat. Prod. Res. 2018, 32, 1353-1356. [CrossRef]

40. Chen, M.; Chai, W.; Song, T.; Ma, M.; Lian, X.-Y.; Zhang, Z. Anti-glioma Natural Products Downregulating Tumor Glycolytic Enzymes from Marine Actinomycete Streptomyces sp. ZZ406. Sci. Rep. 2018, 8, 72. [CrossRef]

41. Hyun, K.H.; Yoon, C.H.; Kim, R.K.; Lim, E.J.; An, S.; Park, M.J.; Hyun, J.W.; Suh, Y.; Kim, M.J.; Lee, S.J. Eckol suppresses maintenance of stemness and malignancies in glioma stem-like cells. Toxicol. Appl. Pharmacol. 2011, 254, 32-40. [CrossRef] 
42. Kumar, S.R.; Hosokawa, M.; Miyashita, K. Fucoxanthin: A marine carotenoid exerting anti-cancer effects by affecting multiple mechanisms. Mar. Drugs 2013, 11, 5130-5147. [CrossRef] [PubMed]

43. Zhang, Z.; Chen, L.; Zhang, X.; Liang, Y.; Anjum, K.; Chen, L.; Lian, X.Y. Bioactive Bafilomycins and a New N-Arylpyrazinone Derivative from Marine-derived Streptomyces sp. HZP-2216E. Planta Med. 2017, 83, 1405-1411. [CrossRef] [PubMed]

44. Gong, A.; Guo, P.; Gong, L.; Liang, H. Aplysin suppresses the invasion of glioma cells by targeting Akt pathway. Int. J. Clin. Exp. Med. 2016, 9, 8062-8068.

45. Lv, Y.; Song, Q.; Shao, Q.; Gao, W.; Mao, H.; Lou, H.; Qu, X.; Li, X. Comparison of the effects of marchantin C and fucoidan on sFlt-1 and angiogenesis in glioma microenvironment. J. Pharm. Pharmacol. 2012, 64, 604-609. [CrossRef]

46. Rengarajan, T.; Rajendran, P.; Nandakumar, N.; Balasubramanian, M.P.; Nishigaki, I. Cancer preventive efficacy of marine carotenoid fucoxanthin: Cell cycle arrest and apoptosis. Nutrients 2013, 5, 4978-4989. [CrossRef] [PubMed]

47. Xin, W.; Ye, X.; Yu, S.; Lian, X.Y.; Zhang, Z. New capoamycin-type antibiotics and polyene acids from marine Streptomyces fradiae PTZ0025. Mar. Drugs 2012, 10, 2388-2402. [CrossRef] [PubMed]

48. Zhang, D.; Yi, W.W.; Ge, H.J.; Zhang, Z.Z.; Wu, B. Bioactive Streptoglutarimides A-J from the Marine-Derived Streptomyces sp. ZZ741. J. Nat. Prod. 2019, 82, 2800-2808. [CrossRef]

49. Wätjen, W.; Ebada, S.; Bergermann, A.; Chovolou, Y.; Totzke, F.; Kubbutat, M.; Lin, W.; Chaidir, C. Cytotoxic effects of the anthraquinone derivatives $1^{\prime}$-deoxyrhodoptilometrin and (S)-(-)-rhodoptilometrin isolated from the marine echinoderm Comanthus sp. Arch. Toxicol. 2016, 91. [CrossRef]

50. Tabunoki, H.; Saito, N.; Suwanborirux, K.; Charupant, K.; Satoh, J.-I. Molecular network profiling of U373MG human glioblastoma cells following induction of apoptosis by novel marine-derived anti-cancer 1,2,3,4-tetrahydroisoquinoline alkaloids. Cancer Cell Int. 2012, 12, 14. [CrossRef] [PubMed]

51. Borbone, N.; De Marino, S.; Iorizzi, M.; Zollo, F.; Debitus, C.; Esposito, G.; Iuvone, T. Minor steroidal alkaloids from the marine sponge Corticium sp. J. Nat. Prod. 2002, 65, 1206-1209. [CrossRef]

52. Iwamaru, A.; Iwado, E.; Kondo, S.; Newman, R.A.; Vera, B.; Rodriguez, A.D.; Kondo, Y. Eupalmerin acetate, a novel anticancer agent from Caribbean gorgonian octocorals, induces apoptosis in malignant glioma cells via the c-Jun NH2-terminal kinase pathway. Mol. Cancer Ther. 2007, 6, 184-192. [CrossRef]

53. Neupane, R.P.; Parrish, S.M.; Neupane, J.B.; Yoshida, W.Y.; Yip, M.L.R.; Turkson, J.; Harper, M.K.; Head, J.D.; Williams, P.G. Cytotoxic Sesquiterpenoid Quinones and Quinols, and an 11-Membered Heterocycle, Kauamide, from the Hawaiian Marine Sponge Dactylospongia elegans. Mar. Drugs 2019, 17, 423. [CrossRef]

54. Biegelmeyer, R.; Schröder, R.; Rambo, D.F.; Dresch, R.R.; Carraro, J.L.F.; Mothes, B.; Moreira, J.C.F.; Junior, M.L.C.d.F.; Henriques, A.T. Sphingosines Derived from Marine Sponge as Potential Multi-Target Drug Related to Disorders in Cancer Development. Mar. Drugs 2015, 13, 5552-5563. [CrossRef]

55. Song, T.; Chen, M.; Chai, W.; Zhang, Z.; Lian, X.-Y. New bioactive pyrrospirones C-I from a marine-derived fungus Penicillium sp. ZZ380. Tetrahedron 2018, 74, 884-891. [CrossRef]

56. Yu, S.; Ye, X.; Huang, H.; Peng, R.; Su, Z.; Lian, X.Y.; Zhang, Z. Bioactive sulfated saponins from sea cucumber Holothuria moebii. Planta Med. 2015, 81, 152-159. [CrossRef] [PubMed]

57. Tsuji, S.; Nakamura, S.; Maoka, T.; Yamada, T.; Imai, T.; Ohba, T.; Yako, T.; Hayashi, M.; Endo, K.; Saio, M.; et al. Antitumour Effects of Astaxanthin and Adonixanthin on Glioblastoma. Mar. Drugs 2020, 18, 474. [CrossRef] [PubMed]

58. Maia, M.; Resende, D.I.S.P.; Durães, F.; Pinto, M.M.M.; Sousa, E. Xanthenes in Medicinal Chemistry-Synthetic strategies and biological activities. Eur. J. Med. Chem. 2021, 210, 113085. [CrossRef] [PubMed]

59. Daina, A.; Michielin, O.; Zoete, V. SwissADME: A free web tool to evaluate pharmacokinetics, drug-likeness and medicinal chemistry friendliness of small molecules. Sci. Rep. 2017, 7, 42717. [CrossRef]

60. Loureiro, D.R.P.; Magalhães, Á.F.; Soares, J.X.; Pinto, J.; Azevedo, C.M.G.; Vieira, S.; Henriques, A.; Ferreira, H.; Neves, N.; Bousbaa, H.; et al. Yicathins B and C and Analogues: Total Synthesis, Lipophilicity and Biological Activities. ChemMedChem 2020, 15, 749-755. [CrossRef]

61. Mahmoud, B.S.; AlAmri, A.H.; McConville, C. Polymeric Nanoparticles for the Treatment of Malignant Gliomas. Cancers 2020, 12, 175. [CrossRef]

62. D'Aquino, R. Good Drug Therapy: It's Not Just the Molecule-It's the Delivery. Chem. Eng. Progress 2004, 100, 15S-17S.

63. Re, F.; Gregori, M.; Masserini, M. Nanotechnology for neurodegenerative disorders. Maturitas 2012, 73, 45-51. [CrossRef]

64. Janjua, T.I.; Rewatkar, P.; Ahmed-Cox, A.; Saeed, I.; Mansfeld, F.M.; Kulshreshtha, R.; Kumeria, T.; Ziegler, D.S.; Kavallaris, M.; Mazzieri, R.; et al. Frontiers in the treatment of glioblastoma: Past, present and emerging. Adv. Drug Deliv. Rev. 2021, 171, 108-138. [CrossRef] [PubMed]

65. Haque, S.; Md, S.; Alam, M.I.; Sahni, J.K.; Ali, J.; Baboota, S. Nanostructure-based drug delivery systems for brain targeting. Drug Dev. Ind. Pharm. 2012, 38, 387-411. [CrossRef]

66. Wicki, A.; Witzigmann, D.; Balasubramanian, V.; Huwyler, J. Nanomedicine in cancer therapy: Challenges, opportunities, and clinical applications. J. Control. Release 2015, 200, 138-157. [CrossRef] [PubMed]

67. Alphandery, E. Nano-Therapies for Glioblastoma Treatment. Cancers 2020, 12, 242. [CrossRef]

68. Lam, F.C.; Morton, S.W.; Wyckoff, J.; Vu Han, T.-L.; Hwang, M.K.; Maffa, A.; Balkanska-Sinclair, E.; Yaffe, M.B.; Floyd, S.R.; Hammond, P.T. Enhanced efficacy of combined temozolomide and bromodomain inhibitor therapy for gliomas using targeted nanoparticles. Nat. Commun. 2018, 9, 1991. [CrossRef] 
69. Fang, C.; Wang, K.; Stephen, Z.R.; Mu, Q.; Kievit, F.M.; Chiu, D.T.; Press, O.W.; Zhang, M. Temozolomide nanoparticles for targeted glioblastoma therapy. ACS Appl. Mater. Interfaces 2015, 7, 6674-6682. [CrossRef] [PubMed]

70. Ramalho, M.J.; Sevin, E.; Gosselet, F.; Lima, J.; Coelho, M.A.N.; Loureiro, J.A.; Pereira, M.C. Receptor-mediated PLGA nanoparticles for glioblastoma multiforme treatment. Int. J. Pharm. 2018, 545, 84-92. [CrossRef] [PubMed]

71. Bertucci, A.; Prasetyanto, E.A.; Septiadi, D.; Manicardi, A.; Brognara, E.; Gambari, R.; Corradini, R.; De Cola, L. Combined Delivery of Temozolomide and Anti-miR221 PNA Using Mesoporous Silica Nanoparticles Induces Apoptosis in Resistant Glioma Cells. Small 2015, 11, 5687-5695. [CrossRef]

72. Irani, M.; Mir Mohamad Sadeghi, G.; Haririan, I. A novel biocompatible drug delivery system of chitosan/temozolomide nanoparticles loaded PCL-PU nanofibers for sustained delivery of temozolomide. Int. J. Biol. Macromol. 2017, 97, 744-751. [CrossRef]

73. Gürten, B.; Yenigül, E.; Sezer, A.D.; Altan, C.; Malta, S. Targeting of temozolomide using magnetic nanobeads: An in vitro study. Braz. J. Pharm. Sci. 2020, 56. [CrossRef]

74. Cui, Y.; Xu, Q.; Chow, P.K.; Wang, D.; Wang, C.H. Transferrin-conjugated magnetic silica PLGA nanoparticles loaded with doxorubicin and paclitaxel for brain glioma treatment. Biomaterials 2013, 34, 8511-8520. [CrossRef]

75. Norouzi, M.; Yathindranath, V.; Thliveris, J.A.; Kopec, B.M.; Siahaan, T.J.; Miller, D.W. Doxorubicin-loaded iron oxide nanoparticles for glioblastoma therapy: A combinational approach for enhanced delivery of nanoparticles. Sci. Rep. 2020, 10, 11292. [CrossRef] [PubMed]

76. Michael, J.S.; Lee, B.-S.; Zhang, M.; Yu, J.S. Nanotechnology for Treatment of Glioblastoma Multiforme. J. Transl. Int. Med. 2018, 6, 128-133. [CrossRef] [PubMed]

77. Wei, X.; Gao, J.; Zhan, C.; Xie, C.; Chai, Z.; Ran, D.; Ying, M.; Zheng, P.; Lu, W. Liposome-based glioma targeted drug delivery enabled by stable peptide ligands. J. Control. Release 2015, 218, 13-21. [CrossRef]

78. Zhou, J.; Patel, T.R.; Sirianni, R.W.; Strohbehn, G.; Zheng, M.-Q.; Duong, N.; Schafbauer, T.; Huttner, A.J.; Huang, Y.; Carson, R.E.; et al. Highly penetrative, drug-loaded nanocarriers improve treatment of glioblastoma. Proc. Natl. Acad. Sci. USA 2013, 110, 11751-11756. [CrossRef]

79. Zhang, P.; Hu, L.; Yin, Q.; Feng, L.; Li, Y. Transferrin-modified c[RGDfK]-paclitaxel loaded hybrid micelle for sequential blood-brain barrier penetration and glioma targeting therapy. Mol. Pharm. 2012, 9, 1590-1598. [CrossRef]

80. Garanti, T.; Stasik, A.; Burrow, A.J.; Alhnan, M.A.; Wan, K.W. Anti-glioma activity and the mechanism of cellular uptake of asiatic acid-loaded solid lipid nanoparticles. Int. J. Pharm. 2016, 500, 305-315. [CrossRef]

81. Alves, A.; Correia-da-Silva, M.; Nunes, C.; Campos, J.; Sousa, E.; Silva, P.M.A.; Bousbaa, H.; Rodrigues, F.; Ferreira, D.; Costa, P.C.; et al. Discovery of a New Xanthone against Glioma: Synthesis and Development of (Pro)liposome Formulations. Molecules 2019, 24, 409. [CrossRef] 